\title{
Habitat-dependent growth in a Caribbean sea urchin Tripneustes ventricosus: the importance of food type
}

\author{
Silvia Maciá $\cdot$ Michael P. Robinson
}

Received: 1 October 2007 / Revised: 21 January 2008 / Accepted: 5 May 2008 / Published online: 10 June 2008

(C) Springer-Verlag and AWI 2008

\begin{abstract}
The sea urchin Tripneustes ventricosus is a common, yet relatively poorly known, grazer of seagrass beds and coral reefs throughout the Caribbean. We compared the size and abundance of urchins between adjacent seagrass and coral reef habitats (where macroalgae are the dominant primary producers). We also conducted a laboratory experiment comparing the growth rate of juvenile urchins fed a diet of either macroalgae or seagrass. Reef urchins had significantly larger test diameter than those in the seagrass on some sampling dates. This size difference may be at least partially explained by diet, because laboratory-reared urchins fed macroalgae grew significantly faster than those fed seagrass. The seagrass population, however, was stable over time, whereas the reef population exhibited strong fluctuations in abundance. Overall, our study indicates that both the seagrass and coral reef habitats are capable of supporting healthy, reproductive populations of T. ventricosus. Each, however, appears to offer a distinct advantage: faster growth on the reef and greater population stability in the seagrass.
\end{abstract}

Keywords Coral reef - Seagrass ·

Tripneustes ventricosus · Habitat selection · Food quality

Communicated by L. Gimenez.

S. Maciá $(\bowtie)$

School of Natural and Health Sciences, Barry University,

11300 NE 2 Ave, Miami Shores, FL 33161, USA

e-mail: smacia@mail.barry.edu

M. P. Robinson

Department of Biology, University of Miami,

P.O. Box 249118, Coral Gables, FL 33124, USA

\section{Introduction}

Coral reefs and seagrass beds are structurally distinct habitats with different primary producers. Primary production on many coral reefs is dominated by diverse species of macroalgae, whereas seagrass beds are dominated by a few species of seagrass (Iverson and Bittaker 1986; Gallegos et al. 1993; Dawes et al. 1995; Aronson and Precht 2000; Lirman and Biber 2000; Kendall et al. 2004). Seagrasses contain relatively high levels of indigestible, refractory compounds and high $\mathrm{C} / \mathrm{N}$ ratios (Duarte 1990, 1992; Enriquez et al. 1993; Anesio et al. 2003; Montague et al. 2005; Vichkovitten and Holmer 2005). On the other hand, many species of macroalgae, while low in refractory components, contain secondary compounds or calcareous deposits that deter grazers (Hay et al. 1987, 1988; Hay 1991; Littler and Littler 2000; Payri 2000; Taylor et al. 2002; Jormalainen and Honkanen 2004; Hemmi et al. 2005; Rees et al. 2007). The food resources available to herbivores are thus fundamentally different between coral reefs and seagrass beds.

The sea urchin Tripneustes ventricosus is an ecologically important grazer of seagrass beds and coral reefs of the tropical western Atlantic, and in some areas is the dominant invertebrate herbivore (Moore and McPherson 1965; Keller 1983; Tertschnig 1989; Woodley et al. 1999; Haley and Solandt 2001). Tripneustes ventricosus is a large urchin, reaching a test diameter of $130 \mathrm{~mm}$ (Tertschnig 1989). The gonads are edible and form the basis of economically important fisheries on certain Caribbean islands (Scheibling and Mladenov 1987; Smith and Berkes 1991).

Although $T$. ventricosus is typically associated with seagrass habitats, in recent years increasing numbers of this urchin have been observed on coral reefs (Woodley et al. 1999; Haley and Solandt 2001; Moses and Bonem 2001). 
Grazing by these urchins could potentially remove macroalgae from the reef (Woodley et al. 1999; Moses and Bonem 2001) and help create suitable recruitment sites for corals. If the $T$. ventricosus populations on the reef are maintained at least in part by recruitment, the reproductive behavior of the urchins could have important implications for the reef community. Fertilization rates in echinoids depend largely on individual fecundity and conspecific density (Pennington 1985; Levitan 1988; Levitan et al. 1992). Thus the ability of a habitat to sustain a population of a given fecundity and density is critical to the reproductive success of $T$. ventricosus. Our study compares the size and abundance of $T$. ventricosus in two adjacent but contrasting habitats in which this species is found: coral reefs and seagrass beds.

\section{Materials and methods}

Study site

We conducted our study in St Ann's Bay on the north coast of Jamaica (Fig. 1). The study site encompasses a patch reef, Frances Reef, adjacent to a shallow (1-2 m) seagrass bed consisting primarily of turtlegrass, Thalassia testudinum. The patch reef rises vertically approximately $2-2.5 \mathrm{~m}$ above the surrounding seafloor. The seagrass bed, which is separated from the patch reef by a narrow $(<2 \mathrm{~m})$ strip of bare sand, has little topographic relief. Despite their proximity, the two habitats provide different food sources and physical complexity: the patch reef is highly rugose and dominated by various species of macroalgae while the seagrass bed is flat and dominated by a single species, $T$. testudinum.

We sampled the macroalgal community of the reef crest in February 2001, February 2002, and July 2002. We

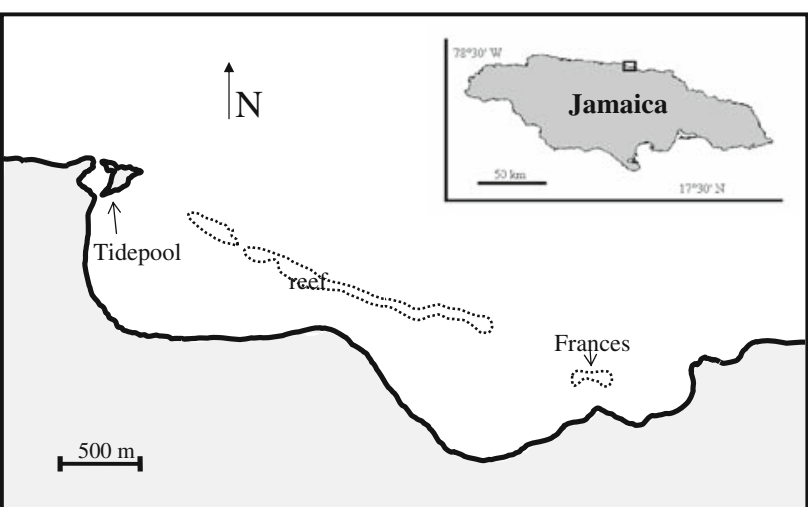

Fig. 1 Map of St Ann's Bay, Jamaica showing the Frances Reef study site. Box in inset of Jamaica in upper right indicates location of enlarged map collected samples by removing all of the algae from ten haphazardly placed $0.04 \mathrm{~m}^{2}$ quadrats (Maciá 2000) laid on the substratum. This quadrat size provided a representative sample of the macroalgal community while minimizing variation and impacts on the benthic community. The samples were rinsed, sorted to genus, and dried to constant weight at $70^{\circ} \mathrm{C}$. The seagrass community was investigated as part of a separate ongoing monitoring program of seagrass communities in St Ann's Bay. Quarterly surveys of the T. testudinum population were conducted from November 2000 to February 2002. At each survey we collected all aboveground biomass within 15 random $0.04 \mathrm{~m}^{2}$ quadrats. The samples were washed in $8.5 \%$ phosphoric acid to remove calcareous epiphytes, and dried to constant weight at $70^{\circ} \mathrm{C}$.

We identified a total of 19 genera of algae on the reef crest. On all sampling occasions, the algal community was dominated by Amphiroa and Halimeda, with several other genera (Gelidium, Turbinaria, Dictyota, Galaxaura, Digenia) present in substantial amounts (Fig. 2). Six other macroalgal genera were observed on certain sampling dates, but these algae never had a mean biomass greater than $10 \mathrm{~g} \mathrm{~m}^{-2}$. Total biomass of macroalgae on the reef throughout the study period ranged from 830 to $1,164 \mathrm{~g} \mathrm{~m}^{-2}$. In the seagrass bed aboveground biomass of $T$. testudinum ranged from 32 to $53 \mathrm{~g} \mathrm{~m}^{-2}$. No other species of seagrass was found in the sampling quadrats, although some Halodule wrightii was observed at the site.

Reef versus seagrass: urchin size

We compared the test diameters of randomly selected T. ventricosus from reef crest and seagrass habitats. We began our study in November 2000 with the intention of sampling twice a year thereafter (winter and summer), but in February 2001 we could find only ten urchins on the

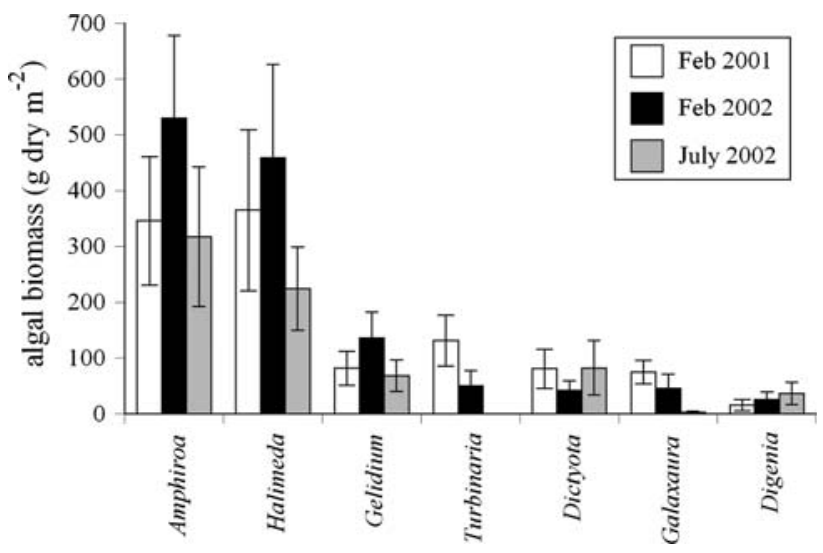

Fig. 2 Biomass (mean \pm SE) of common genera of macroalgae on the reef crest at Frances Reef. Common genera defined as those with biomass of at least $10 \mathrm{~g} \mathrm{~m}^{-2}$ during one or more sampling periods 
entire reef crest. We measured the gut contents of five of these urchins but there were not enough individuals to construct a size frequency histogram of test diameter. The abundance of urchins on the reef remained close to zero until February 2002, when urchins reappeared and we resumed sampling. Test diameter of randomly selected urchins was measured with calipers in November 2000 ( $n=100$ in each habitat), February $2002(n=70)$ and July $2002(n=100)$.

We analyzed gut content of five urchins from each of the habitats in February 2001 and July 2002. Gut contents of each urchin were homogenized and a subsample (ca. $5 \mathrm{ml}$ ) preserved in ethanol. These subsamples were spread evenly in a petri dish with a $5 \times 5 \mathrm{~mm}$ grid drawn on the bottom. Particles located within 20 randomly selected sections of the grid were identified with a dissecting microscope. We then classified each grid section as macroalgae, seagrass, or "other" based on which type of food particle constituted the majority of particles for that section.

\section{Growth rate experiment}

We determined the effect of diet type on the growth of twenty juvenile $T$. ventricosus maintained in the laboratory. All urchins were collected from the Frances Reef seagrass bed immediately prior to the start of the experiment. Individual urchins were randomly assigned to either a seagrass or reef-macroalgal diet, and initial mean test diameters of the two groups did not differ significantly (seagrass: $36.0 \pm 1.0 \mathrm{~mm}$; reef: $36.8 \pm 1.4 \mathrm{~mm} ; t$ test: $t=0.496,18$ $d f, P=0.63)$. Urchins were kept in a single water table on an open seawater system. The water table was divided into 20 equally sized compartments, each of which held one urchin. Urchins and treatments were assigned randomly to these compartments. Urchins were fed ad libitum: every 67 days we removed any remaining food and added newly collected food to ensure a constant and sufficient supply of seagrass or algae. Seagrass was collected by removing all of the aboveground biomass from fifteen $0.04 \mathrm{~m}^{2}$ quadrats randomly located in the Frances Reef seagrass bed. All of the seagrass blades were combined and thoroughly stirred, then distributed to each experimental compartment. To ensure that a representative selection of algae was provided to the urchins, we collected all algal biomass within ten $0.04 \mathrm{~m}^{2}$ quadrats randomly placed on the Frances Reef crest. These samples were then combined and thoroughly stirred so that the algae were distributed evenly throughout. We distributed the mixed algae equally among the appropriate water table compartments.

We measured the test diameter of the urchins every 2 weeks for 10 weeks. To minimize variability in the measurements, we measured each individual urchin three times at each sampling and used the mean of these three values in the statistical analyses. Because not all urchins survived for the duration of the experiment, we standardized growth increments as a weekly increment for each individual urchin. In each treatment nine of the ten urchins survived for at least 5 weeks, and 14 of these 18 urchins survived for at least 8 weeks. Growth data from the remaining two urchins, which died after only 2 weeks, were not used in the statistical analyses. There was no significant difference $(t$ test: $t=2.12,16 d f, P=0.68)$ in the number of weeks survived by urchins in the seagrass treatment $(8.67 \pm$ 0.55 weeks $)$ and the algae treatment $(8.33 \pm 0.56$ weeks $)$.

\section{Results}

\section{Reef versus seagrass: urchin size}

The mean test diameters of urchins did not differ between habitats (Sheirer-Ray-Hare extension of Kruskal-Wallis test: $H=2.216 ; P=0.14)$ or among sampling dates $(H=1.355 ; P=0.51)$, but there was a significant interaction of these two factors $(H=17.663 ; P<0.001)$. Because we were interested primarily in the effects of habitat on the urchins, we used a series of sequentially Bonferroni-corrected (Rice 1989) Mann-Whitney $U$ tests to compare urchin size in reef and seagrass habitats separately for each sampling date. In November 2000, urchins on the reef were significantly larger than those in the seagrass (Table 1). Urchin test diameter did not differ significantly between the seagrass and reef in either February or July 2002 (Table 1).

The size frequency distribution of urchin test diameter on the reef crest in July 2002 was strongly bimodal, however, and differed in shape from the unimodal distribution observed in the seagrass (2-sample Kolmogorov-Smirnov test: $P<0.0001$; Fig. 3 ). These data suggest that there were two separate cohorts present on the reef in July, but only a single cohort in the seagrass. Splitting the July reef data into two groups (i.e., $>75 \mathrm{~mm}$ or $\leq 75 \mathrm{~mm}$ test diameter) greatly improved the fit of the data to a normal distribution (Lilliefors tests for normality: combined group $P \ll 0.0001$; larger cohort $P=0.700$, smaller cohort $P=0.231$ ). A similar split of the seagrass data resulted in a poorer fit to a normal distribution (combined group $P=0.028$; larger cohort $P<0.001$, smaller cohort $P<0.001$ ). The test diameters of the $>75 \mathrm{~mm}$ reef cohort were significantly larger than those of the entire seagrass urchin population (Table 1). The test diameters of the larger reef cohort were also significantly larger than those of seagrass urchins that were $>75 \mathrm{~mm}$ (Table 1).

In February 2001, gut contents of urchins from the reef crest were $98 \pm 1.2 \%$ (mean $\pm \mathrm{SE}$ ) macroalgae, while the gut contents of seagrass urchins were $94 \pm 2.4 \%$ seagrass. There was little change in July 2002: $92 \pm 3.4 \%$ macroal- 
Table 1 Test diameters of Tripneustes ventricosus urchins in two habitats, reef and seagrass

\begin{tabular}{|c|c|c|c|c|c|c|}
\hline \multirow[t]{2}{*}{ Sampling date } & \multicolumn{2}{|c|}{ Mean $( \pm$ SE) test diameter $(\mathrm{mm})$} & \multicolumn{2}{|c|}{ Median test diameter (mm) } & \multirow[t]{2}{*}{$U$} & \multirow[t]{2}{*}{$P$} \\
\hline & Reef & Seagrass & Reef & Seagrass & & \\
\hline November 2000 & $90.1 \pm 2.0$ & $75.4 \pm 1.5$ & 97.8 & 80.4 & 7614 & $<0.001$ \\
\hline February 2002 & $81.3 \pm 2.0$ & $83.7 \pm 1.2$ & 84.2 & 84.7 & 2514 & 0.789 \\
\hline July 2002 & $74.5 \pm 2.1$ & $84.1 \pm 0.7$ & 81.8 & 83.6 & 5577.5 & 0.316 \\
\hline July $>75 \mathrm{~mm}$ reef versus all seagrass & $92.2 \pm 0.9$ & $84.1 \pm 0.7$ & 92.1 & 84.2 & 4407.5 & $<0.001$ \\
\hline July $>75 \mathrm{~mm}$ reef versus $>75 \mathrm{~mm}$ seagrass & $92.2 \pm 0.9$ & $85.3 \pm 0.6$ & 92.1 & 84.2 & 3967.5 & $<0.001$ \\
\hline
\end{tabular}

In July 2002 subsamples of urchins with test diameters $>75 \mathrm{~mm}$ were used in some analyses (see text and Fig. 3) Mann-Whitney $U$ tests compared test diameters between habitats within a sampling period. Probabilities were corrected with the sequential Bonferroni method (Rice 1989)

Statistically significant differences are indicated in boldface

Fig. 3 Size frequency histograms of Tripneustes ventricosus urchin test diameter in two habitats during three sampling $N=100$ urchins measured in each habitat in November and July; $n=70$ for each in March dates at the Frances Reef site.

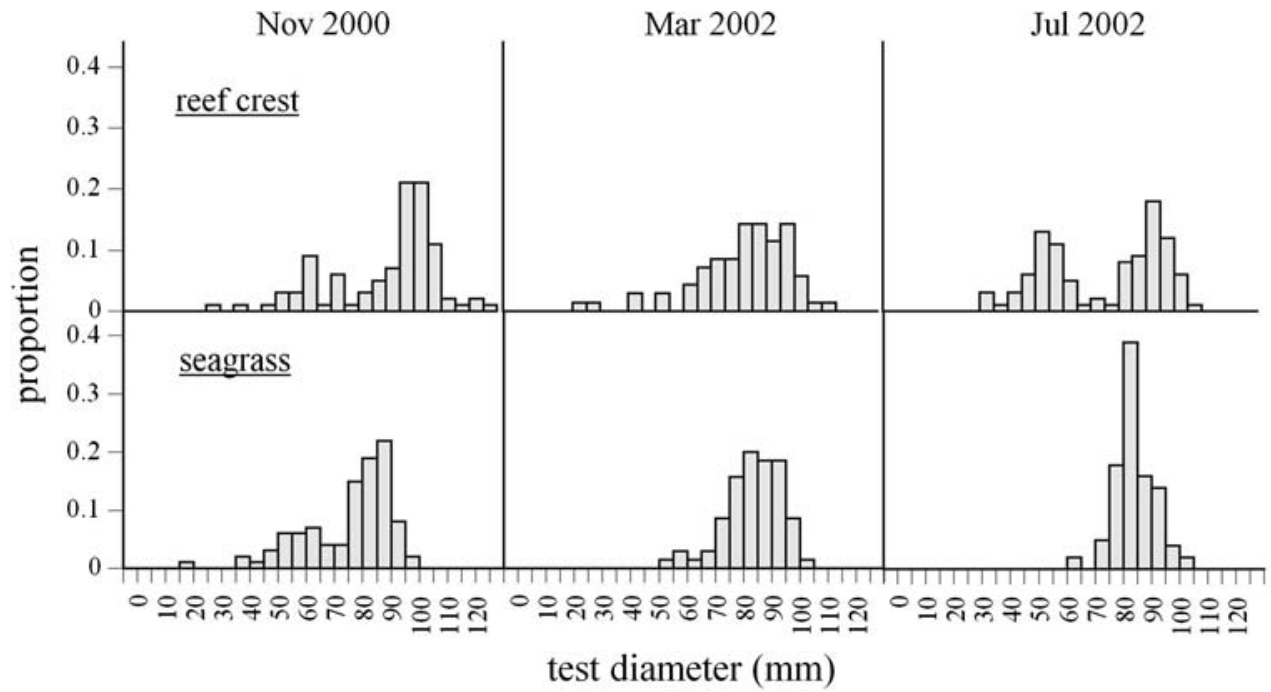

gae for urchins on the reef and $93 \pm 3.7 \%$ seagrass for urchins in the seagrass.

Growth rate experiment

Tripneustes ventricosus fed a diet of macroalgae grew significantly faster $\left(0.45 \pm 0.11 \mathrm{~mm}^{-1} \mathrm{wek}^{-1}\right)$ than those fed seagrass $\left(0.14 \pm 0.07 \mathrm{~mm} \mathrm{week}^{-1} ; t\right.$ test on $\ln (x+1)$ transformed data: $d f=15 ; t=2.50 ; P=0.02$; Fig. 4). Only one urchin in the algae treatment exhibited negative growth, compared with four in the seagrass treatment.

\section{Discussion}

We found important differences in mean size, size distribution and growth of the sea urchin Tripneustes ventricosus between seagrass and coral reef habitats. Overall, urchins on the reef tended to be larger than those in the seagrass: urchin size was either larger in the reef habitat (November 2000) or similar in the two habitats, but was never significantly larger in the seagrass. In July 2002 the reef urchin

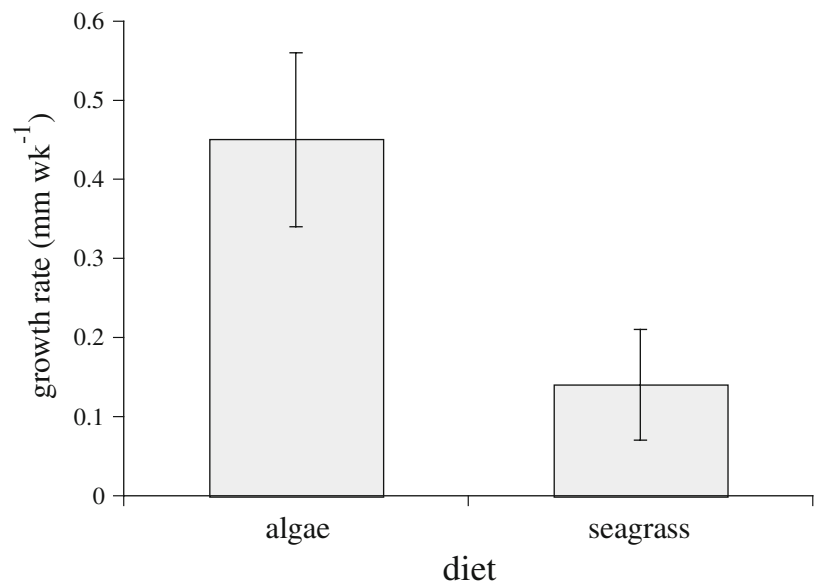

Fig. 4 Growth rates (mean \pm SE) of juvenile Tripneustes ventricosus fed macroalgae or seagrass under laboratory conditions. Urchins fed macroalgae grew significantly faster than those fed seagrass $(P=0.02)$

population was strongly bimodal, possibly representing two cohorts. The seagrass population was unimodal at this time, indicative of a single cohort. This seagrass cohort was 
significantly smaller than the presumably similarly-aged reef cohort (i.e., reef urchins $>75 \mathrm{~mm}$ ).

Differences in food availability or quality may account for the observed differences in sea urchin size and growth. Although the aboveground biomass of seagrass was an order of magnitude lower than that of macroalgae on the reef crest, we did not observe any overgrazing of seagrass by the urchins in the seagrass bed. The lack of overgrazing indicates that these urchins were not limited by the abundance of seagrass. Therefore, the difference observed in urchin size between the two habitats does not appear to be caused by differences in the abundance of food. Urchins on the reef may be larger because, as indicated by our laboratory feeding experiment, their food source supports faster growth.

The growth rate of $T$. ventricosus is higher on a diet of the macroalga Sargassum than on a diet of seagrass (Lilly 1979). In laboratory tests $T$. ventricosus preferred the alga Dictyota cervicornis over seagrass (T. testudinum) and the alga Galaxaura oblongata, but exhibited no preference between the latter two (Prince et al. 2004). In our experiment, $T$. ventricosus that were fed several species of macroalgae grew three times faster than urchins fed seagrass alone. Thus a diet of macroalgae supports a greater growth rate in $T$. ventricosus than does a diet of seagrass, although not all species of macroalgae are preferred over seagrass. An alternative explanation for the size difference between reef and seagrass urchins is that the larger reef cohort was in fact older than the seagrass cohort. We cannot rule out this possibility without knowing the age of the urchins.

In addition to differences in urchin size between the coral reef and seagrass habitats, there were differences in population abundance between the two habitats. From November 2000 to July 2002, the seagrass bed supported a stable population of $T$. ventricosus with a density ranging from 1.0 to 2.5 urchins $\mathrm{m}^{-2}$ (quarterly sampling, unpublished data). In contrast, the reef population exhibited larger fluctuations in density. Sometime between November 2000 and February 2001 virtually all of the reef urchins disappeared, only to reappear in February 2002. In July 2002 we observed a new cohort of urchins on the reef crest, but not in the seagrass. Physical conditions such as temperature, salinity, and wave exposure are relatively uniform throughout the year in $\mathrm{St}$ Ann's Bay (unpublished data), and no tropical storms occurred during our study period. Therefore, we assume that the observed fluctuations in urchin abundance are not driven by such factors. The fluctuations might have been caused by migration of the urchins, but our data do not show a decrease in seagrass urchins as would be expected if they were leaving the seagrass for the reef. Although the reef crest provides a higher-quality food source, its population of urchins was not as stable as that of the seagrass bed.

\section{Conclusions}

Our study compared populations of Tripneustes ventricosus urchins in adjacent seagrass and coral reef habitats. Our data suggest that the coral reef is a nutritionally superior habitat for T. ventricosus which grow faster on a diet of macroalgae than on a diet of seagrass. Nevertheless, urchins in the seagrass habitat are able to grow well beyond the size at which sexual maturity occurs. Urchin populations in the seagrass bed were also more stable over time than those of the coral reef from which T. ventricosus virtually disappeared for an entire year during our study period. Our study indicates that reef and seagrass habitats provide different benefits to T. ventricosus (i.e., faster growth vs. stable population size, respectively). Given the observed fluctuation in abundance of the reef urchins, however, the nutritional benefits of the habitat may be ephemeral.

Acknowledgments We thank Julien Million for his help in the field, and the fishermen of St. Ann's Bay, who have not yet realized that sea urchins are edible. We also thank John Morrissey and the staff of HUML without whose support this research would not have been possible. This manuscript benefited greatly from the helpful comments of two anonymous reviewers. This is contribution \#12 of the Hofstra University Marine Laboratory.

\section{References}

Anesio AM, Abreu PC, Biddanda BA (2003) The role of free and attached microorganisms in the decomposition of estuarine macrophyte detritus. Est Coastal Shelf Sci 56:197-201

Aronson RB, Precht WF (2000) Herbivory and algal dynamics on the coral reef at Discovery Bay, Jamaica. Limnol Oceanogr 45:251-255

Dawes CJ, Hanisak D, Kenworthy WJ (1995) Seagrass biodiversity in the Indian River Lagoon. Bull Mar Sci 57:59-66

Duarte CM (1990) Seagrass nutrient content. Mar Ecol Prog Ser 67:201-207

Duarte CM (1992) Nutrient concentration of aquatic plants. Patterns across species. Limnol Oceanogr 37:882-889

Enriquez S, Duarte C, Sand-Jensen K (1993) Patterns in decomposition rates among photosynthetic organisms: the importance of detritus C:N:P content. Oecologia 94:457-471

Gallegos ME, Merino M, Marba N, Duarte CM (1993) Biomass and dynamics of Thalassia testudinum in the Mexican Caribbean: elucidating rhizome growth. Mar Ecol Prog Ser 95:185-192

Haley MP, Solandt JL (2001) Population fluctuations of the sea urchins Diadema antillarum and Tripneustes ventricosus at Discovery Bay, Jamaica: a case of biological succession? Carib J Sci 37:239-245

Hay M, Fenical W, Gustafson K (1987) Chemical defense against diverse coral-reef herbivores. Ecology 68:1581-1591

Hay MA (1991) Marine-terrestrial contrasts in the ecology of plant chemical defenses against herbivores. Trends Ecol Evol 6:362365

Hay ME, Duffy JE, Fenical W, Gustafson K (1988) Chemical defense in the seaweed Dictyopteris delicatula: differential effects against reef fishes and amphipods. Mar Ecol Prog Ser 48:185-192

Hemmi A, Makinen A, Jormalainen V, Honkanen T (2005) Responses of growth and phlorotannins in Fucus vesiculosus to nutrient enrichment and herbivory. Aquat Ecol 39:201-211 
Iverson RL, Bittaker HF (1986) Seagrass distribution and abundance in eastern Gulf of Mexico coastal waters. Est Coastal Shelf Sci 22:577-602

Jormalainen V, Honkanen T (2004) Variation in natural selection for growth and phlorotannins in the brown alga Fucus vesiculosus. J Evol Biol 17:807-820

Keller BD (1983) Coexistence of sea urchins in seagrass meadows: an experimental analysis of competition and predation. Ecology 64:1581-1598

Kendall MS, Battista T, Hillis-Starr Z (2004) Long term expansion of a deep Syringodium filiformemeadow in St Croix, US Virgin Islands: the potential role of hurricanes in the dispersal of seeds. Aquat Bot 78:15-25

Levitan DR (1988) Asynchronous spawning and aggregative behavior in the sea urchin Diadema antillarum (Philippi). In: Burke RD, Mladenov PV, Lambert P, Parsley PL (eds) Echinoderm biology. A. A. Balkema, Rotterdam, pp 181-186

Levitan DR, Sewell MA, Chia F (1992) How distribution and abundance influence fertilization success in the sea urchin Strongylocentrotus franciscanus. Ecology 73:248-254

Lilly GR (1979) The influence of diet on the oxygen uptake of the sea urchins, Tripneustes ventricosus and Strongylocentrotus droebachiensis. Comp Biochem Physiol 6A:463-470

Lirman D, Biber P (2000) Seasonal dynamics of macroalgal communities of the Northern Florida reef tract. Bot Mar 43:305-314

Littler D, Littler M (2000) Caribbean reef plants. OffShore Graphics, Washington

Maciá S (2000) The effects of sea urchin grazing and drift algal blooms on a subtropical seagrass bed community. J Exp Mar Ecol Biol 246:53-67

Montague JR, Rein K, Mesadieu M, Boulos J (2005) Soluble protein, molar C: $\mathrm{N}$ ratio, and amino acid composition in green vs. decayed seagrass leaves (Thalassia testudinum). Fla Sci 68:44-52

Moore HB, McPherson BF (1965) A contribution to the study of the productivity of the urchins Tripneustes ventricosus and Lytechinus variegatus. Bull Mar Sci 15:855-871
Moses CS, Bonem RM (2001) Recent population dynamics of Diadema antillarum and Tripneustes ventricosus along the north coast of Jamaica W.I. Bull Mar Sci 68:327-336

Payri C (2000) Primary production and calcification of coral reef benthic algae. Oceanis 26:427-463

Pennington JT (1985) The ecology of fertilization of echinoid eggs: the consequences of sperm dilution, adult aggregation, and synchronous spawning. Biol Bull 169:417-430

Prince JS, LeBlanc WG, Maciá S (2004) Design and analysis of multiple choice feeding preference data. Oecologia 138:1-4

Rees SA, Opdyke BN, Wilson PA, Henstock TJ (2007) Significance of Halimeda bioherms to the global carbonate budget based on a geological sediment budget for the Northern Great Barrier Reef, Australia. Coral Reefs 27:177-188

Rice WR (1989) Analyzing tables of statistical tests. Evolution 43:223-225

Scheibling RE, Mladenov PV (1987) The decline of the sea urchin, Tripneustes ventricosus, fishery of Barbados: A survey of fishermen and consumers. Mar Fish Rev 49:62-69

Smith AH, Berkes F (1991) Solutions to the "Tragedy of the Commons': sea-urchin management in St Lucia, West Indies. Env Conserv 18:131-136

Taylor RB, Sotka E, Hay ME (2002) Tissue-specific induction of herbivore resistance: seaweed response to amphipod grazing. Oecologia 132:68-76

Tertschnig WP (1989) Diel activity patterns and foraging dynamics of the sea urchin Tripneustes ventricosus in a tropical seagrass community and a reef environment (Virgin Islands). P S Z N I Mar Ecol 10:3-21

Vichkovitten T, Holmer M (2005) Dissolved and particulate organic matter in contrasting Zostera marina (eelgrass) sediments. J Exp Mar Biol Ecol 316:183-201

Woodley JD, Gayle PMH, Judd N (1999) Sea-urchins exert top-down control of macroalgae on Jamaica coral reefs (2). Coral Reefs $18: 193$ 